\title{
Capacidade informacional sob a lente teórica da teoria das capacidades dinâmicas
}

\author{
Information capability under the lens of the dynamic capabilities theory
}

\author{
José Carlos da Silva Freitas Junior ${ }^{1}$ \\ Antônio Carlos Gastaud Maçada ${ }^{2}$
}

\begin{abstract}
Resumo
O desenvolvimento tecnológico, especialmente após o surgimento da Internet, acelerou o fluxo de dados e informações digitais, levando a um volume crescente de dados e informações. Várias pesquisas têm sido conduzidas no estudo de capacidades que podem contribuir para o desempenho organizacional, entre elas a capacidade de tecnologia da informação e a capacidade de gerenciamento de informações. Há também a capacidade informacional, que foi inicialmente estudada em 2000. A abordagem teórica que tem sido utilizada na maioria das pesquisas é a teoria RBV. No entanto, com um cenário de competitividade crescente de forma imprevisível e rápida, é necessário adaptar-se a ele reconfigurando os recursos e capacidades existentes e, se necessário, desenvolvendo novas capacidades. Assim, este estudo tem como objetivo discutir as capacidades dinâmicas como uma lente teórica para compreender a capacidade informacional, propondo um modelo que contribua para o avanço teórico sobre este tema e melhore o desempenho organizacional.
\end{abstract}

Palavras-chave: Capacidade Informacional; Capacidades Dinâmicas; Visão Baseada em Recursos; Informação

\begin{abstract}
The technological development, especially after the emergence of the Internet, has speeded up the flow of digital data and information,leading to an increasing volume of data and information. Various researches have been conductedon the study of capabilities that might contribute to organizational performance, among them the information technology capability and information management capability. There is also the Information Capability, which was initially studiedin 2000. The theoretical approach mostly used in these researchers has been the RBV theory. However, when a competitive scenario grows unpredictably and rapidly, it is necessary to adapt to it by reconfiguring the existing resources and capabilities and, if necessary, by developing new capabilities. Thus, this study aims to discuss the dynamic capabilities as a theoretical lens to understand the information capability, proposing a model that contributes to the theoretical advance on this topic and enhance organizational performance.
\end{abstract}

Keywords: Information Capability; DynamicCapabilities; Resource-Based View; Information.

\section{Introduction}

The increasing level of technological development has accelerated flows of data and information. Also, these technological advances have also enabled the emergence of novel business models, and now we can see new business at all time, like Airbnb or Uber (Tauscher \& Laudien, 2017). Due to this dynamism of changes, some authors have highlightedthe importance of studying and understanding the increasing volume of data and information and its relations with the Information System (IS) research (Gobble, 2013; Beath et al., 2013; Fernandes et al., 2017).

Doutorando no PPGA da Universidade Federal do Rio Grande do Sul. Mestre em administração pela Universidade do Vale dos Sinos (UNISINOS).Atua como Professor Universitário na Universidade do Vale dos Sinos e como professor no Colégio Militar de Porto Alegre. Temas de interesse: Tecnologia da Informação, Capacidades Digitais, Capacidade de Informação; Processo de Tomada de Decisão e Liderança. Brasil. Afiliação: UniVersidade do Vale do Rio dos Sinos. Lattes: http://lattes.cnpq.br/9070894806445071. Email: freitas1995@gmail.com

2 Mestrado e doutorado em Sistemas de Informação Gerencial em 1993 e 2001, respectivamente, pela Universidade Federal do Rio Grande do Sul (UFRGS). Brasil. Afiliação: Universidade Federal do Rio Grande do Sul. Lattes: http://lattes.cnpq.br/3043897632138906. Email: acgmacada@ ea.ufrgs.br 
According to Bharadwaj et al. (2013), many companies are beginning to see the power of digital resources and understanding the need for new capabilities more comprehensive than IT,such as IT Management and IT Infrastructure, which need to be reconfigured. These authors point to the example of Amazon that has substantially expanded its online retail strategy, encompassing cloud computing services as a key digital resource, aimed at improving the flow of information both internally and externally.

In this sense, some researches have been directed toward the studyof capabilities that canimprove organizational performance by exploring suchflows of data and informationby organizations. Among the studies about capabilities in IS researchwe can highlight the Information Processing Capability (IPC) (Tushman \& Nadler 1978; Wang, Tai \& Grover, 2013), the Information Technology Capability (ITC) (Bharadwaj 2000; Nevo, Wade \&Cook, 2007), and the Information Management Capability (IMC) (Mithas, Ramasubbu \& Sambamurthy, 2011).

Besides, there is the Information Capability (IC) that stillis little discussedin the academic literature. IC began to be studied by Marchand et al.(2000), who presented a model based on the Resource-Based View(RBV) theory. After about ten years, other researchersexplored this topic, among them Mani, Barua and Whinston (2010) and Zárraga-Rodríguez et al. (2014).

Thus, the study of IC is used to understand the relationship between information and business performance. The concept of this capability involves the ability to generate, capture, store, modify, process, and exchange of information throughout the value chain, including customers, suppliers, and partners of the organization, called Information Capacity (Barua et al. 2004; Leonardi 2007).

The theory most used in IC studies has been the RBV (Barney, 1991). However, there is a need to view IC under other theoretical lenses. Because of the huge information speed and volume existing today, organizations need to be more and more agile and able to reconfigure their resources and capabilities(Daniel, Ward,\& Franken 2014).

In this regard, this study aims to examine the IC under the perspective of the Dynamic Capabilities (DC) concept. This theoretical approach points to the need that organizationsmust be able to keep their flexibility by creating capabilities and developing competencies to deal with external pressures (Schwarz et al.2010). The core concept is that when the competitive scenario grows unpredictably and rapidly, it is necessary to adapt to it by improving or redesigning the existing resources and capabilities and, if necessary, developing new ones (Teece, Pisano \& Schuen 1997; Eisenhardt \& Martin 2000).

Thus, this study is a theoretical essay that proposes the dynamic capabilities theory as another theoretical lens to understand IC and contribute to the theoretical advance of this topic in the area of Information Systems (IS). It is crucial to let clear that this paper is not a literature review by itself, but a theoretical discussion which intends to contribute to the IS research field bringing a new approach, under the lens of Dynamic Capabilities, to raise new ideas and to propose propositions that can be explored by further studies.

So, this work is structured as follows: first, the theoretical background is presented with a review of the RBV and DC theories. Subsequently, the methodological procedures and an approach on the IC dimensions under the DC theoretical lens of the DC are presented; finally, in the final considerations are summarized the theories and dimensions, and the study is completed with a schematic drawing of the theoretical model. It is worth noting that this theoretical model has been tested in recent research works and discussed on doctoral dissertations.

\section{Theoretical Background}

In this section, we present a review of the RBV and DC theories.

\subsection{Theories: Resources and Dynamic Capabilities}

The theories that are used in this research are the Resource-Based View theory and the Dynamic Capabilities theory. The study of these approaches is due to its complementarity and because they support studies of capabilities and resources, such as digital capability. 
Although there are some theoretical divergences on the adherence of the same ones, this study is based on the argument of Barney (2001), one of the foremost theorists of the Resource-Based View, and according to him, Dynamic Capabilities theory is not opposed to RBV but instead complements it.

Eisenhardt and Martin (2000) corroborate with this statement emphasizing that Dynamic Capabilities are required, but are not sufficient conditions for competitive advantage, they also argue that DC can be used to enhance existing resource configurations in the pursuit of competitive advantage.

Therefore, it is believed that the combination of these theories provides a complete look at the capabilities surveyed, such as InformationCapability. Then the theory of Resource-Based Vision will be highlighted, and later the Dynamic Capabilities theory will be approached.

\subsubsection{Resource-Based View}

The theory of the RBV began to develop from the ideas of Penrose (1959) that had a Schumpeterian foundation, as highlighted by herself. She argues that the company is made up of people and resources and can survive its founders, thus introducing an idea, albeit incipient, of sustainability.

Subsequently, some other authors have contributed to this theory, such as Ansoff (1977), who sought to identify strategies that enable companies to develop and maintain a competitive advantage that ensures that they achieve and sustain superior performance.

This new way of looking at organizations came against the focus of the strategic studies of the 1970s and 1980s which followed a logic of analyzing the external environment of companies and then building their strategy.

It is possible to illustrate with the typology composed of three generic strategies proposed by Porter (1980), known as total cost leadership; differentiation and focus, in all these cases the positioning was aimed at the competition. The RBV, on the other hand, suggests that the strategy should emerge from within the organization outwardly, focusing on the identification and development of resources and capabilities that will generate advantages in a competitive external environment.

So, in the 1980s and 1990s, the RBV theory began to be more widely recognized and was developed by Wernerfelt (1984), Barney (1991) and Peteraf (1993). In the following years, several other authors followed, and the theory has been studied until the present day.

The author who presents a more consistent and well-known definition of this theory is Barney (1991) who states that organizations can achieve a competitive advantage and create value from resources that are unique, rare, valuable, and are not easily imitated or replaceable. Also, this author highlights the notion of resources that can be considered as all assets, capabilities, organizational processes, financial resources, physical, human, information, and knowledge.

Given the importance of this theory, many authors have sought to identify or justify specific features as being strategic, and which can contribute to the development of a sustainable competitive advantage by companies.

With this, it has been possible to verify the application of RBV in many areas, such as the Information Systems area. One of the first authors to relate Resource-Based View with IS was Grant (1991), according to which the management of information systems provides a fragmented image of the company's resource-based.

This author acknowledges that the availability of up-to-date information would reflect a competitive advantage. It is worth mentioning that this first conception dates to the beginning of the 1990s. Subsequently, other authors carried out studies establishing relations between Information Systems and RBV.

To illustrate, one can highlight the publications in the MIS Quarterly magazine, whose recognition is well known in academic society, as the studies of Bharadwaj (2000), Sambamurthy, Bharadwaj, and Grover (2003), Wade and Hulland (2004) and Mani, Barua, and Whinston (2010).

Therefore, it is worth mentioning the Resource-Based View theory approach, which points out that organizations can achieve a competitive advantage and create value from resources that are unique, rare, valuable, and are not easily imitated or replaceable (Barney, 1991). Used for the understanding of information capabilities. Following, complementing the RBV, the Dynamic Capability Theory will be studied. 


\subsubsection{Dynamic Capability}

The theory of Dynamic Capability is defined as the ability to integrate, build and reconfigure internal and external competences to respond to rapid environmental changes and adopts as a conceptual basis process involving capabilities characterized by dynamism, accelerated environmental turbulence and processes of innovation and renewal continuous (Teece et al., 1997).

Helfat and Peteraf (2009) complement this definition by stating that the dynamic capabilities of an organization purposefully allow it to create, extend and modify its resource base. This author also emphasizes that this theory points out the need for firms to respond to changes in the environment.

Such changes have become non-linear and less predictable. Consequently, the models of success in business are not precise, and the actors of the market are ambiguous or are changing. In this context, dynamic capabilities are necessarily based much less on existing knowledge, and much more on new specific and situational awareness quickly created (Eisenhardt \& Martin, 2000).

This theoretical perspective of DC arises from RBV's unclear response to how organizations gain a competitive advantage in a dynamic or changing context (Ambrosini \& Bowman, 2009). This theory argues that the differences between organizations are generated by new combinations of resources and capabilities developed by organizations along with their trajectory (Teece et al., 1997).

Regarding the relationship between DC and RBV, some literature criticisms point to an excess of fragmentation in the field of study of the strategy and do not see the complementarity between DC and RBV (Green, Covin \& Slevin, 2008).

However, many other studies have pointed out the opposite, that is, Dynamic Capabilities theory complements the RBV to bring the organization to competitive advantage (Peteraf, 1993; Teece et al., 1997; Eisenhardt \& Martin, 2000). Based on this theoretical line that this study is supported.

To illustrate, Eisenhardt and Martin (2000) who defend the understanding of the dynamic capabilities providing an improvement of the RBV performance. For these, dynamic capabilities are drivers behind the creation, evolution, and recombination of other resources into new sources of competitive advantage, which can also be defined as the ability to copy, transfer, and recombine resources, especially those based on knowledge within the company.

In the same vein, Barney (2001) revisiting his seminal study recognizes the complementarity between the RBV and the Dynamic Capabilities theory. Therefore, dynamic capabilities cross-functional relationships and provide fast communication between those involved in the process and the external market.

Regarding people and information in real time, it will allow the alert from the beginning of any action enabling a more significant reaction time for adjustments that are necessary for the face of problems and opportunities from the information (Eisenhardt \& Martin, 2000).

According to Eisenhardt and Martin (2000), real-time information also builds the intuition about the market in such a way that managers can understand the situation of change more quickly and adapt to it, allowing an improvement in the decision-making process.

About the relationship between the area of Information Systems and the Dynamic Capability theory, Pavlou and El Sawy (2006) show that dynamic capabilities can be developed as enterprise information technology (IT) capabilities, for example. Similarly, this theory gives support to the study of the Information Capability that seeks to provide the character of instantaneous information (Barua et al., 2004; Karimi \& Walter, 2015).

Lastly, it is important to highlight that the reconfiguration of operational capabilities and the implementation of new capabilities to meet turbulent environments is the goal of dynamic capabilities that seek to achieve evolutionary aptitude and prevent organizational rigidity (Teece, 2007).

Hence, the characteristics of DC that are the ability to integrate, construct and reconfigure internal and external competences to respond to rapid environmental changes (Teece et al., 1997) will be used to understand Information Capability.

Also, we can note that the RBV emphasizes the choice or selection of the appropriate resource (s), while the dynamic capabilities emphasize the development and renewal of these and resources and the 
development of new organizational changes. The following item addresses the concepts of capabilities, resources, and competences to define the concepts developed in this research.

\subsubsection{Competence, Capability and Resource}

The RBV and DC study presents some concepts that can sometimes overlap and complement each other. Like this, aiming to avoid divergent interpretations and to highlight the conceptual line of the present study the central concepts for skills, resources and competences are presented below.

The first distinction between resources and capabilities is that the former refers to the productive assets owned by the company while the capabilities are what the company can do. Individual resources do not confer competitive advantage; they must work together to build organizational capability (Grant, 2010).

Besides that, in Grant's (1991) conception, resources are inputs to the production of processing, they are the primary units of analysis. The company's assets include capital goods items, each employee's skills, patents, brands, finances and so on.

Resources can still be classified as tangible and intangible assets and human resources. Examples of tangible assets are capital, equipment, facilities, and raw materials. For intangible assets, examples may be the skills, judgment, perception, and experiences of individual employees, as well as information and trademarks and patents (Barney, 1991).

Capabilities according to Amit and Schoemaker (1993) and Bharadwaj (2000) refer to the organization's ability to gather, integrate, and distribute valuable resources, usually in combination with other features and capabilities.

According to these authors, the skills may come from the skills of the employees and the structure and resources of the organization. Skills are developed when combinations of resources are applied together to create specific organizational skills (Teece et al., 1997).

Fleury and Fleury (2001, p.189) corroborate with the authors explaining that "competence would thus be the ability to combine, mix and integrate resources into products and services," and must be associated with a systematic learning process, which involves discovery/innovation and human resource training.

Regarding the hierarchical level, Javidan (1998) points out that at the bottom of the hierarchy are the resources. They are the building blocks of skills. Resources are the inputs to the organization's value chain. Already the capabilities refer to the ability of the company to explore and combine its resources, being the second level in the hierarchy.

Competence is the third level because it is the integration and coordination of capabilities. At the top are the core competences, which are the core competences that distinguish an organization.

Table 1 below summarizes the main concepts discussed in this section and will serve as a basis for the continuation of this research. They are ordered according to the hierarchy of competences of Javidan (1998).

Table 1 - Theoretical Concepts

\begin{tabular}{|c|c|c|}
\hline Hierarchy of competences & Definition & Authors \\
\hline Core Competences & $\begin{array}{l}\text { It is a set of abilities that are spread by the organization, } \\
\text { distinguishing it from its competitors }\end{array}$ & Javidan, 1998. \\
\hline Competences & $\begin{array}{l}\text { It is a set of abilities, routines, and assets difficult to imitate } \\
\text { that they take the organization to reach its objectives using the } \\
\text { organizational processes. }\end{array}$ & $\begin{array}{l}\text { Amit; Schoemaker, } \\
\text { 1993; Teece; Pisano; } \\
\text { Shuen } 1997 .\end{array}$ \\
\hline Capability & $\begin{array}{l}\text { The ability of an organization is mentioned to it to combine, } \\
\text { to mount, to integrate and to implant valuable resources, } \\
\text { generally, in combination or with the use of organization } \\
\text { processes and other capabilities for the desired end. }\end{array}$ & $\begin{array}{l}\text { Amit; Schoemaker, } \\
\text { 1993; Bharadwaj, } \\
2000 .\end{array}$ \\
\hline Resource & $\begin{array}{l}\text { They are assets that can be tangible, intangible and personal, } \\
\text { and which serve as the organization's primary unit of } \\
\text { analysis, but that without being mobilized does not generate a } \\
\text { competitive advantage for the organization. }\end{array}$ & $\begin{array}{l}\text { Grant, 1991; } \\
\text { Amit; Schoemaker, } \\
\text { 1993; } \\
\text { Bharadwaj, 2000. }\end{array}$ \\
\hline
\end{tabular}

Source: the author, based on the hierarchy of competences of Javidan (1998). 
In short, companies create competitive advantage by pooling resources that work together by developing organizational capabilities (Bharadwaj, 2000). In this context, an element is fundamental, the information since according to Amit and Schoemaker (1993) the capabilities are based on the development, flow and exchange of information by the company's human capital and of them with the clients and other external actors. As will be shown, the information capability according to several authors are based on the RBV, but according to what we can see from the above review, the Dynamic Capabilities have characteristics that compel the RBV, therefore, it may complement the Information Capability it will be demonstrated next.

\section{Methodological Procedures}

We developed a systematic literature review of information capability. The analysis and validation of the articles were made according to the model of literature review proposed by Biolchini et al. (2007)and Wolfswinkel et al. (2013) which includes some step. Initially, we follow Biolchini et al. (2007) that suggest three phases: planning, execution,and analysis of results.

So, firstly we developed the review protocol. Second, we identified the inclusion and exclusion criteria for relevant publications. Third, we performed an in-depth search of studies, followed by critical appraisal.

The first step was the development of a protocol for search and execution that was established, which is detailed below. The protocolestablished the main research key-words that guided the selection of papers, the search strategy, inclusion, and quality criteria, as well as the method of synthesis. The review process was driven by the following term information capability.

According to Wolfswinkel et al. (2013) before starting the search, it is necessary to establish some definitions, such as: define the criteria for inclusion/exclusion; identify the fields of research; determine the appropriate sources and decide on the specific search terms. The author suggests that the criteria for inclusion/exclusion may restrict the kinds of publication outlets, setting a particular threshold such as the impact factor of an outlet; or one may determine a particular time frame of the publication. Table 1 brings the Inclusion and Exclusion Criteria.

Table 2. Inclusion and Exclusion Criteria

\begin{tabular}{l|l}
\hline Inclusion Criteria & Exclusion Criteria \\
\hline $\begin{array}{l}\text { Investigations which focus on information } \\
\text { capability and discuss key characteristics }\end{array}$ & $\begin{array}{l}\text { Investigations which deliver no attributes/capabilities/ } \\
\text { components or insights for the understanding the concept of } \\
\text { information capability }\end{array}$ \\
\hline $\begin{array}{l}\text { Papers from a journal which uses a double- } \\
\text { blind review }\end{array}$ & $\begin{array}{l}\text { Papers from conferences and any other source but the } \\
\text { qualified journal }\end{array}$ \\
\hline
\end{tabular}

Source: the authors

The next step is to identify fields of research, determine appropriate sources, and decide on specific search terms (Wolfswinkel et al., 2013). We conducted a bibliographic search for articles containing the terms "information capability" and "information capabilities" in the database of the Association for Information Systems (AIS) library. We focused on the Senior Scholars Basket of Eight of Journals, which AIS defines as the top IS journals, namely: European Journal of Information Systems, Information Systems Journal, Information Systems Research, Journal of the Association for Information Systems (JAIS), Journal of Information Technology, Journal of Management Information Systems, Journal of Strategic Information Systems, and MIS Quarterly. Additionally, we also searched in EBSCOhost and the Web of Science database for the same terms, researching only papers from journals that adopted the double-blind review.

After all these definitions, the next steps proposed by Wolfswinkel et al. (2013) are "search" and "select." In these phases, the searches are done, and the results are refined. In our study, the search and selection of the papers occurred from January $2-18,2018$. The following search parameters were utilized: publications 
in the last 20 years and academic articles. During this execution, the abstract, keywords, and introduction were read. In addition to following the inclusion/exclusion criteria, for an article to be included in the study, it must have been related to IS and addressed the information capability topic.

After the searches were found 53 results. Afterward, an analysis of the results was made, and it was found that 17 publications were duplicated, which were disregarded, thus remaining 36 publications in diverse areas of knowledge.

About the third phase, as proposed by Biolchini et al. (2007), the analysis of the articles was made by the authors following a protocol designed to collect information to support the study. In the first phase, the abstract, introduction and final considerations were read to find if they fit the topic, i.e., if they addressed IC, DC and RBV topics. Then, all articles dealing with the IC, DC and RBV topicswere read in full, and the IC and Dimensions were categorized. Finally, the remaining articles were read to complement the study.

Once the papers have been chosen, Wolfswinkel et al. (2013) indicate going to the analysis and the presentation structure of the results. In this study, we used the software NVivo to support the analysis. First, we read all the papers, and then we utilized open coding to create tentative labels for chunks of data to summarize our understanding. We looked for definitions for information capability, what the main capabilities required by digital business are, the challenges for digital business, and so on.

Next, we started the axial coding to identify relationships among the open codes and then we went to the selective coding to figure out the core variable that includes all of the data. So, we were able to correlate the IC with the theories and come with some results that will be presentedin the next section. What is the last ofthis phase as suggested by Wolfswinkel et al. (2013), called "PRESENT" we represent and structure the content and structure the article which is present next.

\section{Expanding the Theoretical Lens to IC}

Firstly, it should be kept in mind that the DCs theory does not exclude RBV. Furthermore, as already explained in the introduction, the choice of DCs as another lens to understand IC is because this concept has been used in other recent research studies in the area of Information Systems to relate DC with RBV. In the next sections, IC will be examined according to these theories, the first according to RBV to determine the dimensions of this approach and then under the lens of the dynamic capabilities' theory, which is the central focus of this study.

\subsection{Information Capability}

The information capability concept was first introduced by Marchand, Kettinger,and Rollins (2000). In the following years, other authors brought contributions to researches on IC. Zárraga-Rodríguez et al. (2014) followed the same line of the first study, adopting the same definition but researching in different contexts. Other authors brought new contributions and perspectives to IC, such as Li, Van Heck and Vervest (2009) and Mani, Barua, and Whinston (2010).

According to Li, Van Heck and Vervest (2009), IC can be defined as the firm's ability to gather complete information on what, when, where and how about its customers. In short, according to these authors, it is necessary to enhance the ability to manage information flows and reduce uncertainty.

Mani, Barua, and Whinston (2010) argue that this capability is associated with an improvement in the amount and quality of information, which will reduce demand uncertainty considerably. Therefore, it can be seen that there is no specific concept for this capability. To broaden the understanding of the IC concept, table 2 presents the definitions found in the literature review. 
Table 3: Concepts of Information Capability

\begin{tabular}{|c|c|c|c|}
\hline Authors & Concepts of Information Capability & Journal & Theory \\
\hline $\begin{array}{l}\text { Marchand, } \\
\text { Kettinger,and } \\
\text { Rollins (2000) }\end{array}$ & $\begin{array}{l}\text { IC is the capability that facilitates an effective } \\
\text { use and management of information to add } \\
\text { value to the strategic business orientation. }\end{array}$ & $\begin{array}{c}\text { Sloan Management } \\
\text { Review }\end{array}$ & RBV \\
\hline Li et al. (2009) & $\begin{array}{l}\text { It is the ability to deal with information flows } \\
\text { to reduce uncertainty. It also aims to gather } \\
\text { complete information on customers (what, } \\
\text { when, where and how). }\end{array}$ & $\begin{array}{l}\text { European Journal of } \\
\text { Information Systems }\end{array}$ & RBV \\
\hline $\begin{array}{l}\text { Mani, Barua, and } \\
\text { Whinston }(2010)\end{array}$ & $\begin{array}{l}\text { It refers to the creation of mechanisms } \\
\text { through which users and the firm's } \\
\text { information sources can coordinate their } \\
\text { behaviors and actions to deal with processes } \\
\text { information requirements and improve } \\
\text { business performance. }\end{array}$ & MIS Quarterly & $\begin{array}{c}\text { Information } \\
\text { processing view } \\
\text { (IPV) }\end{array}$ \\
\hline $\begin{array}{l}\text { Zárraga- } \\
\text { Rodríguez and } \\
\text { Alvaréz (2013) }\end{array}$ & $\begin{array}{l}\text { Under a managerial perspective, it is the } \\
\text { capability that makes easier the effective use } \\
\text { and management of information to add value } \\
\text { to the firm's strategic orientation. }\end{array}$ & $\begin{array}{c}\text { Total Quality } \\
\text { Management }\end{array}$ & RBV \\
\hline $\begin{array}{l}\text { Zárraga- } \\
\text { Rodríguez et al. } \\
\text { (2014) }\end{array}$ & $\begin{array}{l}\text { The ability to use and manage information } \\
\text { effectively to make it a source of competitive } \\
\text { advantage for the firm. }\end{array}$ & $\begin{array}{l}\text { Revista de } \\
\text { Globalización, } \\
\text { Competitividad \& } \\
\text { Gobernabilidad }\end{array}$ & RBV \\
\hline $\begin{array}{l}\text { Youn et al. } \\
(2014)\end{array}$ & $\begin{array}{l}\text { The firm can identify, use and assimilate } \\
\text { information both internally and externally } \\
\text { to facilitate information sharing and } \\
\text { development of competence on theinter- } \\
\text { organizational relationship. }\end{array}$ & $\begin{array}{l}\text { International Journal } \\
\text { of Information } \\
\text { Management }\end{array}$ & RBV \\
\hline
\end{tabular}

Source: the authors

It is worth noting that most of these IC concepts were presented based on resources and capabilities examined under the lens of the RBV theory, as can be seen in Table 2 above. However, taking into account the dynamics of current environment and the increasing amount of data and information, as underlined in the Introduction of this study, it is believed that the IC study under another theoretical approach, such as the dynamic capabilities, may contribute to theoretical advancement on the topic and the achievement of sustainable competitive advantage.

\subsection{IC under the Theoretical Lens of RBV}

In Barney's view (1991), IC can lead an organization to gain acompetitive advantage because it results from a set of internal resources and capabilities that place the organization in a favorable position relative to its competitors.

It should be noted that information here is viewed as a resource (Zárraga-Rodríguez Et Al. 2014; Tallon, Ramirez and Short 2014) and must be unique, rare, valuable and not easily imitable or replaceable. Uniqueness refers to the specificity of a resource and rarity to the condition that the resource is not concurrently available to a large number of firms(Amit and Schoemaker 1993; Grant 1991). So, the organization must attempt to develop abilities forits specific use and management of information and not easily accessible to other firms (Zárraga-Rodríguez et al. 2014). 
Besides meeting the abovementioned RBV premises, as information is a resource and so that it generates competitive advantage, it must be mobilized through its information capability (Grant 1991; Amit and Schoemaker 1993; Bharadwaj 2000). This will occur usingcapabilities and skills that comprise the IC (Marchand, Kettinger and Rollins 2000; Mani, Barua and Whinston 2010;Zárraga-Rodríguez et al. 2014), which will be discussed in the next section.

\subsection{IC under the Theoretical Lens of DC}

Besides the conditions presented by the resource-based view, the dynamic capabilities theory requires that the firm must attempt to integrate, build and reconfigure the internal and external resources so that the business gains acompetitive advantage (Teece, Pisano and Schuen 1997).

A study conducted by Mani, Barua, and Whinston (2010) points out that IC should be able to adjust the amount of information necessary to deal with uncertainty. IC must reconfigure their resources to be able to process information properly to reduce uncertainty and improve the ability to decide so that the organization may achieve the desired performance.

Reconfiguration refers to the transformation and recombination of assets and resources. Therefore, when analyzing the information capability under the lens of DC, IC must allow the integration, building,and reconfiguration of their capabilities and resources expeditiously so that the information helps improve the organizational performance, as described in the premises presented by Teece, Pisano, and Schuen (1997).

Therefore, IC must have more capabilities than those presented by RBV, and with these additional capabilities and skills, it can improve the existing capabilities and skills, allowing the firm to attain speed, accuracy, and cost-savings in exploring the innovation opportunities and competitive action (Sambamurthy et al. 2003) and also be able to deal with new demands or environmental changes rapidly (Lu and Ramamurthy 2011).So, the first proposition of this study is accomplished, meeting the presented argument.

P1: The Information Capability can be understood under the DC lens.

\subsection{IC Dimensions}

To improve organizational performance and achieve competitive advantage is necessary to understand how information must be put at the service of the organization, which will be possible using IC (Marchand, Kettinger and Rollins 2000). It is worth noting that technical resources include material assets of the information technology such as hardware, software, and networks (Armstrong and Sambamurthy, 1999; Bharadwaj, 2000). This classification meets Grant (2010)'s proposal, which also considers resources like tangible, intangible and human resources.

Complementarily, studies conducted by Pavlou and El Sawy (2006) and Teece (2007) indicate the need that the organization must have to integrate, transform and reconfigure its resources and capabilities to develop the organizational capabilities. It is worth noting that IS-related human resources refer to the competencies of the information systems staff (Bharadwaj2000).

It can be seen that the capability can be broken down into a series of material and observable capabilities. So, from the literature review, it was possible to identify the capabilities/skills that comprise the Information Capability. In this study, such capabilities will be referred to as IC dimensions. Analysing table3it is possible to understand these dimensions and the respective authors' definition better. 
Table 4 - Dimensions of the Information Capability

\begin{tabular}{|c|c|c|}
\hline Authors & Capabilities & Definition \\
\hline \multirow{3}{*}{$\begin{array}{l}\text { Marchand, } \\
\text { Kettinger, } \\
\text { and Rollins } \\
(2000)\end{array}$} & $\begin{array}{l}\text { Information } \\
\text { Technology }\end{array}$ & $\begin{array}{l}\text { A firm's ability to effectively manage IT applications and support } \\
\text { infrastructure to decision-making processes and operational } \\
\text { communication. }\end{array}$ \\
\hline & $\begin{array}{l}\text { Information } \\
\text { management }\end{array}$ & A firm's ability to generate information efficiently throughout its lifecycle. \\
\hline & $\begin{array}{l}\text { Values and } \\
\text { Human } \\
\text { Behaviors }\end{array}$ & $\begin{array}{l}\text { A firm's ability to instill values and promote behaviors in the employees for } \\
\text { effective use of information. }\end{array}$ \\
\hline \multirow{3}{*}{$\begin{array}{l}\text { Mani, } \\
\text { Barua,and } \\
\text { Whinston } \\
(2010)\end{array}$} & $\begin{array}{l}\text { Governance } \\
\text { structure }\end{array}$ & $\begin{array}{l}\text { The hierarchical agents' ability to reduce incentive failures throughbetter } \\
\text { monitoring and control and coordination characteristics to reduce cognitive } \\
\text { failures in work-partition networksthrough the formalization of roles, shared } \\
\text { ownership,and more systematization. }\end{array}$ \\
\hline & $\begin{array}{l}\text { Relational } \\
\text { Processes }\end{array}$ & $\begin{array}{l}\text { Besides allowing information-sharing promptly, it aids to overcomediverse } \\
\text { interpretation of changes in the information environment by the company's } \\
\text { user and provider to develop shared understandings. }\end{array}$ \\
\hline & Technology & $\begin{array}{l}\text { Processing technologies that enable the timely adoption of information } \\
\text { changes in the execution of the coordination process and technologies that } \\
\text { increase the amount and frequency of information exchange by companies } \\
\text { to reduce theoverload of information in the relationship. }\end{array}$ \\
\hline \multirow{3}{*}{$\begin{array}{l}\text { Zárraga- } \\
\text { Rodríguez } \\
\text { and Alvarés } \\
\text { (2013); } \\
\text { Zárraga- } \\
\text { Rodríguez } \\
\text { et al. (2014) }\end{array}$} & $\begin{array}{l}\text { Information } \\
\text { management }\end{array}$ & $\begin{array}{l}\text { It is defined as the firm's ability to manage information effectively over the } \\
\text { period that information is being used. }\end{array}$ \\
\hline & $\begin{array}{l}\text { Information } \\
\text { technology }\end{array}$ & $\begin{array}{l}\text { The organization should have technologies and define processes } \\
\text { to keepdatabases updated to ensure that people are using the best } \\
\text { information available. }\end{array}$ \\
\hline & $\begin{array}{l}\text { Information } \\
\text { culture }\end{array}$ & $\begin{array}{l}\text { The organization values people who share sensitive information rather than } \\
\text { manipulating or hiding it for their own benefit. }\end{array}$ \\
\hline
\end{tabular}

Source: the authors

By analyzing Table3, it can be seen that the dimensions presented by different authors converge in three broad groups, one related to information management, another to information technology and a third one related to people. The first dimension, therefore, is IMC.

What Mani, Barua,and Whinston (2010) call relational processes, Zárraga-Rodríguez and Alvarés (2013) and Zárraga-Rodríguez et al. (2014) call information culture, which is aligned with the values and human behavior described by Marchand Kettinger and Rollins (2000). Therefore, this second dimension will be called Human Capability $(\mathrm{HC})$ and is supported by the RBV, considering the characteristics of this theory as emphasized by Mani, Barua, and Whinston (2010) and Marchand, Kettinger, and Rollins (2000), but not by $D C$ as highlighted in figure 1 below

The third dimension is the Information Technology capability, although Mani, Barua, and Whinston (2010) call technology only, referring to the information technology and the other authors define it as ITC. These three dimensions, IMC, HC, andITCare studied by the authors based on the theoretical fundamentals of the Resource-Based View.

IMC, as defined by Mithas, Ramasubbu, and Sambamurthy (2011) and Carmichael et al. (2011), has as abilities, not only the management of information captured or received, but, access and distribution. Thus, it is expected that CGI will impact on information capability

However, IMC can also be explained through the lens of the Dynamic Capabilities, as pointed out by Brinkhues, Maçada, and Casalinho (2014). According to Mithas, Ramasubbu, and Sambamurthy (2011), IMC is a facilitator of organizational capabilities. Information management has been defined as the application of management principles to the acquisition, organization, control, dissemination, and use of information (Choo et al. 2006). So, the second proposition of this study is the following: 
P2: Dynamic capabilities help understand that Information Management Capability is an IC dimension.

It is also worth noting that the leading theory that supports the study of IT capabilities is RBV, which classifies the Information Systems of an organization by relating them with resources into three major categories: technical, human and intangible. Grant (2010) who corroborates that IT is related to the functional capability as one management capability of the information system. Moreover, an IT infrastructure provides the IT shared support to build business applications and is usually managed by a group of information systems, being able to adapt to changes quickly(Brinkhues, Freitas Jr and Maçada 2015).

Firms should develop the ability to gain visibility into their processes so that they can react to problems or changes. Information plays an important role in enabling information capability. While the capability to gather data from the environment is critical to producing useful information, the organizational value of information comes when the collected data are analyzed through data mining (Kohli \& Grover, 2008, p. 32).

The Big Data revolution has brought about new challenges such as information overload. Aakus et al. (2014, p. 1194) propose new strategies for approaching big data, in particular how to advance the analytics of unstructured textual data for theoretical and practical ends. What reinforces the ITC role as part of IC dimension.

Thus, the IT capabilities approach under the lens of DC enables to differentiate and link them to strategic organizational processes, which, in turn, are not limited to a single and exclusive financial perspective. Therefore, the third proposition of this study is that

P3: the dynamic capability helps understand that the Information Technology Capability is an IC dimension.

By analyzing more specifically the premises of dynamic capabilities, it can be seen that resources building, and integration may occurusing the information management capability, but reconfiguration is a more specific capability and should be a dimension per se. This dimension meets Teece's view(2007), who advocates that the reconfiguration of operational capabilities and implementation of new capabilities are the ultimate objectives of DC.

This capability allows to reconfigure data and information resources and capabilities and will possibly meet the required agility, accuracy and costs savings by exploiting innovation opportunities and competitive actions(Sambamurthy et al. 2003), which are vital in today's scenario of high speed and volume of information.

The reconfiguration capability configures the resources with punctuality and efficiency, in order to implement a new configuration that corresponds to the new environment (Wei \& Wang, 2010). This capability is explicit to the definition of IC except for environmental change. However, the implicit goal of providing information at appropriate levels to usurers is that this can serve to meet the rearrangement needs of organizational resources.

According to Daniel, Ward, and Franken (2014), organizations must be able to redesign their processes, resources,and capabilities quickly in response to environmental, business and information changes that arise every moment. Thus, IC will enable the organization to deal quickly with information arisen from new demands or market changes (Lu and Ramamurthy 2011).

The IC is also intended to be an ability to reconfigure the Information Infrastructure itself to meet changes in the environment (Mithas, Ramasubbu \& Sambamurthy, 2011). The theoretical propositions are also based on the presuppositions of the DC. They are the firm's ability to integrate and reconfigure internal and external competencies to respond to changes in the environment (Teece et al., 1997).

In addition, the very changes in the informational environment, which require Dynamic Capabilities (Pavlou \& El Sawy, 2010), is that they associate them with more evidence to such complexity that involves the IMC environment, Therefore, the third proposition is that IC must have reconfiguration capability (RcfC).

P4: the dynamic capability helps understand that the Reconfiguration Capability is an IC dimension.

Finally, according to Tallon, Ramirez,and Short (2014), Information Governance is a set of capabilities or practices designed to create, gather, assess, store, use, control, access, save and delete information over its lifecycle, considering a dynamic environment. The authors explain that Information Governance can be examinedthrough the lens of RBV and dynamic capabilities. DCshows the importance of this governance 
having control instruments and practices that enable the organization to deal with information in an environment of rapid changes and generation of new knowledge.

To Peterson (2000) Information Governance Capability (IGov C) is generally defined as the locus of IT decision-making authority. IGovC involves structures, processes, and stakeholders that support and shape the direction and coordination of IT-based business developments based on dynamic capability criteria such as the ability to copy, transfer, and recombine resources.

Additionally, according to Bharadwaj (2000), one of the IT capabilities is the IT Governance (ITGov), i.e., ITGov is an ITC. Considering that ITC is an IC, analogously it is possible to infer that IGov is an IC, which corroborates the theoretical analysis of the Information Governance concepts.

Therefore, the Information Governance Capability (IGovC) can be considered an IC dimension through the lens of DC. It can be defined as the ability to govern theorganizational information through norms, directives and responsibility controls that will contribute to the integration, learning,and redesign of the organizational resources:

P5: dynamic capability helps understand that the Information Governance Capability is an IC dimension.

It is therefore verified that Information Governance Capability (IMC) (Mithas, Ramasubbu, \& Sambamurthy (2011), Information Governance Capability (IGovC) (Tallon, Ramirez, \& Short, 2014; Bharadwaj ), Information Technology Capability(ITC) (Brinkhues, Freitas Jr \& Maçada 2015) and Human Capability (HC) (Marchand, Kettinger, \& Rollins, 2000) are described by their authors as IC dimensions, that are supported by the RBV theory.

However, during the explanation of the propositions in this study it was verified that these dimensions are also understood in the light of the DC, whose concept of Teece et al. (1997, p. 516) defines as "the firm's ability to integrate, build and reconfigure internal and external competencies to respond rapidly to changes in the environment." Therefore, Reconfiguration Capability Daniel, Ward, and Franken (2014) were integrated, which in itself is already explained as being supported by DC. Next, Figure 1 illustrates the theoretical model with the propositions described above.

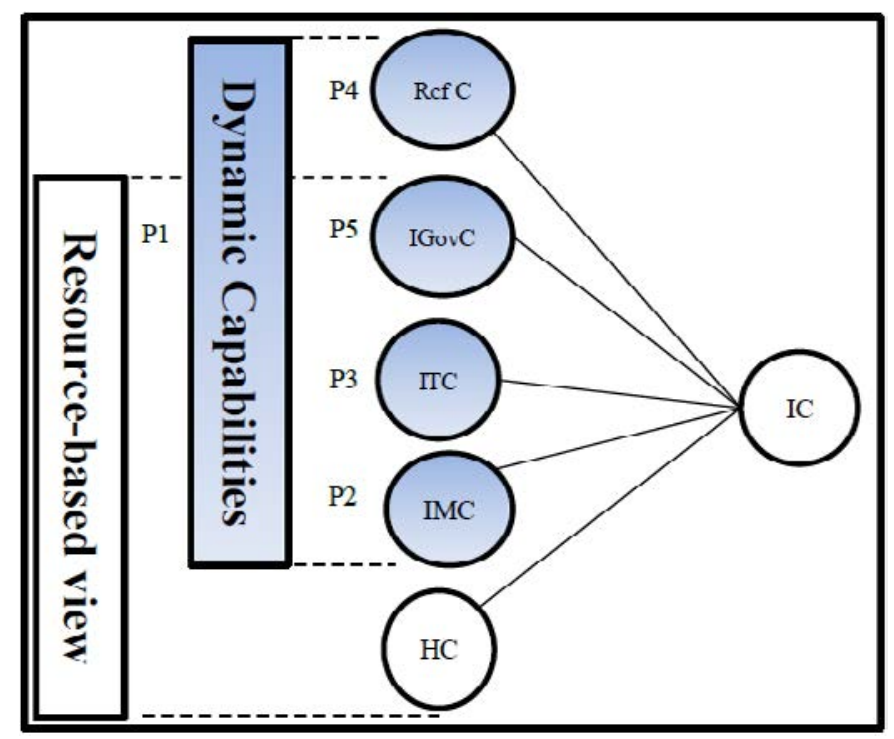

Fig 1. Conceptual Model: IC dimensions under the DC perspective

The figure aims to show that the dynamic capabilities theory, as another theoretical lens, complements RBV. Shaded areas represent the five propositions presented and also new IC dimensions. As demonstrated in this study, the figure also shows that both theories can analyze ITC, IGovC, and IGC.

Hence, by knowing the resources and capabilities that comprise the information capability, organizations will be able to develop it according to their context, because, as stated by Barney (2001, p. 631), the set of capabilities must be evaluated in the context they operate. 
This understanding is corroborated by propositions $\mathrm{P} 2, \mathrm{P} 3, \mathrm{P} 4$, and $\mathrm{P} 5$ and is illustrated in the theoretical model shown in Fig. These propositions support the argument of this study, which underlines that IC can improve, combine and, when needed, reconfigure the IC resources and capabilities.

\section{Final Remarks}

The present paper presented a theoretical study on information capabilitiesbased on the primary argument that the dynamic capabilities theory, as another theoretical lens, helps understand IC and also explains that it can improve, combine and, when necessary, reconfigure their resources and capabilities (IC dimensions).So, this paper showed this new approach, under the lens of Dynamic Capabilities, raised new ideas and presented five propositions that can be explored by further studies.

First, it was possible to see that RBV has already been studied to explain IC. However, considering the current state of the organizational scenario and the need for agility and dynamicity, the study aimedto analyze IC under the theoretical lens of DC. The theoretical rationale presented led to the first proposition (P1), which suggests that IC can be understoodthrough the lens of DC. So, itwas demonstrated that this proposition meets the theoretical argument presented.

Also, it was underlined that, according to Grant (2010), an organizational capability is comprised of other capabilities and can even develop new ones incrementally.So, it was possible to establish the propositions illustrated in Fig. 1, which shows the theoretical model with the IC dimensions under the lens of DC.

Finally, the present study proposes a definition for the information capability according to the dynamic capabilities' theory: IC is the capability of effectively reconfiguring, governing and handling the information to promote both the access to information and its processing so that IC becomes a firm's sustained competitive advantage. As a suggestion of future research, we understand that the propositions presented here can be tested by quantitative papers and better understood by qualitative papers.

\section{References}

Aakhus, M., Agerfalk, P. J., Lyytinen, K., \& Te'eni, D. (2014). Symbolic action research in information systems: introduction to the special issue. MIS Quarterly, 38(4), 1187-1200.

Amit, R., \& Schoemaker, P. J. (1993). Strategic Assets and Organizational Rent. Strategic Management Journal, 14 (1), 33-46.

Ansoff, H. (1977). Estratégia empresarial. São Paulo: McGraw-Hill.

Barney, J. (1991). Firm resources and sustained competitive advantage. Journal of Management, 17(1), $99-120$.

Barney, J. B. (2001). Resource-based theories of competitive advantage: A ten-year retrospective on the resource-based view. Journal of Management, 27(6), 643-650.

Barua, A., Konana, P., Whinston, A. B., \& Yin, F. (2004). An empirical investigation of net-enabled business value. MIS Quarterly, 28(4), 585-620.

Beath, C., Fernandez, I. B., Ross, J., \& Short, J. (2012). Finding value in the information explosion. MIT Sloan Management Review, 53(4), 18.

Bharadwaj, A. S. (2000) A resource-based perspective on information technology capability and firm performance: An empirical investigation. MIS Quarterly, 24(1), 169-196.

Bharadwaj, A., El Sawy, O. A., Pavlou, P. A., \& Venkatraman, N. V. (2013). Digital business strategy: Toward a next generation of insights. MIS Quarterly, 37 (2), 471-482.

Biolchini, J. C. A., Gomes, P. M., Natali, A. C. C., Conte, T. U., \& Travassos, G. H. (2007). Scientific research ontology to support systematic review in software engineering. Advanced Engineering Informatics, 21(2), 133-151.

Brinkhues, R., Freitas, J. C. S., \& Júnior, Maçada, A. C. (2015). Information management capability as 
competitive imperfection in the strategic factor market of big data. Paper presented at the Twenty-first Americas Conference on Information Systems, Puerto Rico.

Brinkhues, R. A., Maçada, A. C. G., \& Casalinho, G. D. O. (2014). Information management capabilities: Antecedents and consequences. Paper presented at the Twentieth Americas Conference on Information Systems, Savannah, 2014.

Carmichael, F., Palacios-Marques, D., \& Gil-Pechuan, I. (2011). How to create information management capabilities through web 2.0. The Service Industries Journal, 31(10), 1613-1625.

Chambers, A. D. (1989). Information Management-the key to Corporate Success. Managerial Auditing Journal, 4(2).

Choo, C. W., Furness, C., Paquette, S., Van den Berg, H., Detlor, B., Bergeron, P., \& Heaton, L. (2006). Working with information: Information management and culture in a professional services organization. Journal of Information Science, 32(6), 491-510.

Daniel, E. M., Ward, J. M., \& Franken, A. (2014). A dynamic capabilities perspective of IS project portfolio management. The Journal of Strategic Information Systems, 23(2), 95-111.

Eisenhardt, K. M., \& Martin, J. A. (2000). Dynamic capabilities: What are they. Strategic Management Journal, 21(1), 1105-1121.

Fernandes, C., Ferreira, J. J., Raposo, M. L., Estevão, C., Peris-Ortiz, M., \& Rueda-Armengot, C. (2017). The dynamic capabilities perspective of strategic management: a co-citation analysis. Scientometrics, 112(1), 529-555.

Fleury, M. T. L., \& Fleury, A. (2001). Construindo o conceito de competência. Revista de Administração Contemporânea, 5(spe.), 183-196.

Gobble, M. M. (2013) Big data: The next big thing in innovation. Research Technology Management, 56(1), 64-66.

Grant, R.(1991). The resource-based theory of competitive advantage: Implications for strategy formulation. California Management Review, 33(3), 114-135.

Grant, R. M. (2010). Contemporary strategy analysis. New York: John Wiley \& Sons.

Green, K. L., Covin, J. G., \& Slevin, D. P. (2008). Exploring the relationship between strategic reactiveness and entrepreneurial orientation: the role of structure-style fit. Journal of Business Venturing, 23, 356383.

Helfat, C. E., \& Peteraf, M. A. (2009). Understanding dynamic capabilities: Progress along a developmental path. Strategic Organization, 7(1), 91-102.

Javidan, M. (1998). Core competence: What does it mean in practice? Long Range Planning, 31(1), 60-71.

Karimi, J., \& Walter, Z. (2015). The role of dynamic capabilities in responding to digital disruption: A factorbased study of the newspaper industry. Journal of Management IS, 32(1), 39-81.

Kohli, R., \& Grover, V. (2008). Business value of IT: An essay on expanding research directions to keep up with the times. Journal of the Association for Information Systems, 9(1), 23-39.

Leonardi, P. M. (2007). Activating the informational capabilities of information technology for organizational change. Organization science, 18(5), 813-831.

Li, T., Van Heck, E., \& Vervest, P. (2009). Information capability and value creation strategy: advancing revenue management through mobile ticketing technologies. European Journal of Information Systems, 18(1), 38-51.

Lu, Y., \& Ramamurthy, K. (2011). Understanding the link between information technology capability and organizational agility: an empirical examination. MIS Quarterly, 35(4), 931-954.

Mani, D., Barua, A., \& Whinston, A. (2010). An empirical analysis of the impact of information capabilities design on business process outsourcing performance. MIS Quarterly, 34(1), 39-62. 
Marchand, D. A., Kettinger, W. J., \& Rollins, J. D. (2000). Information orientation: People, technology, and the bottom line. Sloan Management Review, 41(4), 69-80.

Mithas, S., Ramasubbu, N., \& Sambamurthy, V. (2011). How information management capability influences firm performance. MIS Quarterly, 35(1), 237-256.

Nevo, S., \& Wade, M. R. (2010). The formation and value of IT-enabled resources: Antecedents and consequences of synergistic relationships. MIS Quarterly, 34(1),163-183.

Nevo, S., Wade, M. R., \& Cook, W. D. (2007). An examination of the trade-off between internal and external IT capabilities. The Journal of Strategic Information Systems, 16(1), 5-23.

Pan, G., Pan, S. L., \& Lim, C. (2015). Examining how firms leverage IT to achieve firm productivity: RBV and dynamic capabilities perspectives. Information \& Management, 52(4), 401-412.

Pavlou, P. A., \& El Sawy, O. A. (2006). From IT leveraging competence to competitive advantage in turbulent environments: The case of new product development. Information Systems Research, 17(3), 198-227.

Pavlou, P. A., \& El Sawy, O. A. (2011). Understanding the elusive black box of dynamic capabilities. Decision Sci, 42(1), 239-273.

Penrose, E. T. (1959). The theory of the growth of the firm. New York: John Wiley \& Sons.

Peteraf, M. A. (1993). The cornerstones of competitive advantage: A resource-based view. Strategic Management Journal, 14(3),179-191.

Peterson, R. R. (2000). Emerging capabilities of information technology governance: Exploring stakeholder perspective in financial services. Recuperado de: https://aisel.aisnet.org/cgi/viewcontent.cgi?article=1 189\&context $=$ ecis 2000

Sambamurthy, V., Bharadwaj, A., \& Grover, V. (2003). Shaping agility through digital options: Reconceptualizing the role of information technology in contemporary firms. MIS Quarterly, 27(2), 237263.

Shan, B., Cai, L., Hatfield, D. E., \& Tang, S. (2014). The relationship between resources and capabilities of new ventures in emerging economies. Information Technology \& Management, 15(2), 99-108.

Schwarz, A., Kalika, M., Kefi, H., \& Schwar. (2010). A dynamic capabilities approach to understanding the impact of it-enabled businesses processes and it-business alignment on the strategic and operational performance of the firm. Communications of the Association for Information Systems, 26, 57-84.

Tarafdar, M., \& Gordon, S. R. (2007). Understanding the influence of information systems competencies on process innovation: A resource-based view. Journal of Strategic Information Systems, 16(4), 353-392.

Täuscher, K., \& Laudien, S. M. (2017). Understanding platform business models: A mixed methods study of marketplaces. European Management Journal, 36(3), 319-329. doi:10.1016/j.emj.2017.06.005

Teece, D. J. (2007). Explicating dynamic capabilities: The nature and microfoundations of (sustainable) enterprise performance. Strategic Management Journal, 28(13), 1319-1350.

Teece, D. J., Pisano, G., \& Shuen, A. (1997). Dynamic capabilities and strategic management. Strategic Management Journal, 18(7), 509-533.

Tushman, M. L., \& Nadler, D. A. (1978). Information processing as an integrating concept in organizational design. Academy of Management Review, 3(3), 613-624.

Wade, M., \& Hulland, J. (2004). Review: The resource-based view and information systems research: Review, extension, and suggestions for future research. MIS Quarterly,28(1),107-142.

Wang, E. T. G., Tai, J. C. F., \& Grover, V. (2013). Examining the relational benefits of improved interfirm information processing capability in buyer-supplier dyads. Management Information Systems Quarterly, 37(1), 149-173.

Wernerfelt, B. (1984). A resource-based view of the firm. Strateg Manag J, 5(2),171-180. 
Wei, H. L., \& Wang, E. T. (2010). The strategic value of supply chain visibility: Increasing the ability to reconfigure. European Journal of Information Systems, 19(2), 238-249.

Winter, S. G. (2003). Understanding dynamic capabilities. Strateg Manag J, 24(10), 991-995.

Wolfswinkel, J. F., Furtmueller, E., \& Wilderom, C. P. M. (2013). Using grounded theory as a method for rigorously reviewing literature. European Journal of Information Systems, 22(1), 45-55.

Youn, S. H., Yang, M. G., Kim, J. H., \& Hong, P. (2014). Supply chain information capabilities and performance outcomes: An empirical study of Korean steel suppliers. International Journal of Information Management, 34 (3), 369-380.

Zárraga-Rodríguez, M., Suárez-Baraza, M. F., Jaca, C., Álvarez, M. J., \& Viles, E. (2014). Information capability under different quality management approaches: Gestión y uso eficiente de la información en función del enfoque de calidad adoptado por la organización. GCG: Revista de Globalización, Competitividad \& Gobernabilidad, 8(3), 33-44.

Zárraga-Rodríguez, M., \& Alvarez, M. J. (2013). Exploring the links between information capability and the EFQM business excellence model: The case of Basque Country Quality award winners. Total Quality Management \& Business Excellence, 24(5/6), 539-560.

Submetido em: 20/03/2018

Aprovado em: 05/10/2019 